\title{
A NEW SPECIES OF FRESHWATER SPONGE (PORIFERA:SPONGILLIDAE) OF THE GENUS RADIOSPONGILLA FROM LAKE PEDDER IN TASMANIA
}

\author{
by Andrew W. Osborn, G. Nigel R. Forteath and John Stanisic
}

(with three plates)

\begin{abstract}
Osborn A.W., Forteath, G.N.R. \& Stanisic, J. 2008 (28:xi): A new species of freshwater sponge (Porifera:Spongillidae) of the genus Radiospongilla from Lake Pedder in Tasmania. Papers and Proceedings of the Royal Society of Tasmania 142(2): 39-44. https://doi.org/10.26749/rstpp.142.2.39 ISSN 0080- 4703. Queen Victoria Museum \& Art Gallery, 2 Wellington Street, Launceston, Tasmania 7250, Australia (AWO, GNRF*), Queensland Museum, PO Box 3300, South Brisbane, Queensland 4101, Australia (JS). *Author for correspondence.

Lake Pedder is the home of a number of relictual organisms. One of those, a new species of freshwater sponge of the genus Radiospongilla, is described herein. Radiospongilla pedderensis sp. nov. occurs throughout most of the lake and often is found in very large numbers in many bays. Radiospongilla is widely distributed in tropical and sub-tropical regions of all continents. The pneumatic layer of the gemmule contains numerous abnormal gemmoscleres a condition probably caused by the chemistry of the lake. The morphology and dimensions of the megascleres, gemmoscleres and aberrant gemmoscleres, as well as the location, structure and size of gemmules, are provided for $\boldsymbol{R}$. pedderensis. The sponge is a bright green colour due to intracellular zoochlorellae. Their presence in local members of Radiospongilla has been the subject of considerable speculation but herein they are illustrated for the first time in an Australian species.
\end{abstract}

Key Words: Spongillidae, Radiospongilla pedderensis sp. nov., freshwater sponge, zoochlorellae, Lake Pedder, Tasmania, Australia.

\section{INTRODUCTION}

Lake Pedder is an oligotrophic body of water that is managed as a reservoir. Originally Lake Pedder covered only $5 \%$ of its present shoreline. Dams were completed in 1972 at strategic locations around the perimeter of what was to become the new Lake Pedder and the lake expanded dramatically. It took two years for it to fill to capacity. Thus, the enlarged lake has been in existence for 34 years. Many lengthy fetches are now present: one in excess of $21 \mathrm{~km}$.

Lake Pedder is located in a region of folded Precambrian quartzites while the Serpentine River Valley, now part of the lake, cut through softer phyllites and schist (Kiernan 2001). Soils in the bed of the present lake and those which surround it are typically organic regolith. According to Pemberton (2001) these soils are thought to be muck peat. They vary in depth from as little as $1-10 \mathrm{~cm}$ to deposits that are up to $2 \mathrm{~m}$ in depth (Brown 1999).

At full supply, Lake Pedder contains $3.3 \mathrm{~km}^{3}$ of fresh water, has a surface area of $235 \mathrm{~km}^{2}$ with a shoreline that is equal to $10 \%$ of the coastline of the state of Tasmania and is $308.46 \mathrm{~m}$ above sea level. It is situated wholly within Tasmania's Southwest National Park. For environmental reasons, Tasmanian state legislation stipulates that the surface level of Lake Pedder cannot legally deviate outside the range of 306.93-308.46 m above sea level. As a direct result, Lake Pedder provides a large, remarkably stable environment for cool-temperate aquatic organisms.

An undescribed freshwater sponge of the genus Radiospongilla occurs commonly throughout many habitats in Lake Pedder, the shores of which range from Northings 5264680 and 5235000 and Eastings 416550 and 448280 (GDA 94). Previously no species of Radiospongilla had been recorded from Tasmania.

According to Williams (1980), the only spongillid to have been recorded from Tasmania is Heterorotula nigra (Lendenfeld, 1887) Similarly, Gooderham \& Tsytlin (2002) state that a single spongillid has been recorded from Tasmania, but do not name that species. According to Racek (1969), two spongillid species have been collected from Tasmania. However, both these species were originally named from specimens that were collected on the mainland by Lendenfeld (1887) (Heterorotula nigra) and by Weltner (1895, 1900, 1910) (H. multidentata (Weltner, 1900)). The undescribed species cannot be attributed to either of the above taxa and thus is the third freshwater sponge known to exist in Tasmania. Flynn (1923) recorded an unknown spongillid from a tributary of the Inglis River in the northwest of Tasmania near Wynyard. Unfortunately he did not provide details upon which his classification of Ephydatia multiformis Weltner, 1910 was based. Flynn refers the reader to Weltner (1900) for verification, however; but that article contains no reference to E. multiformis. Rather it concentrates on E. multidentata and it would appear that Flynn was referring to E. multidentata. Racek (1969) concluded that it was not possible to ascribe the sponge discussed therein to its correct genus and species. We concur with that assessment.

The present paper reports the first record of the presence of a species of radiospongillid in Tasmania and concurrently provides the first real evidence of zoochlorellae in any species of radiospongillid in Australia. In the new species, described here, the majority of gemmoscleres are largely abnormal, a condition ascribed to a silica imbalance in the lake's water chemistry (Poirrier et al. 1987).

\section{SYSTEMATICS}

\section{Spongillidae Gray, 1867 \\ Radiospongilla Penney \& Racek, 1968 Radiospongilla pedderenisis $\mathrm{sp}$. nov.}

Type material

Type material deposited in the Queen Victoria Museum \& Art Gallery, Launceston, Tasmania, Australia (registration 
no.: QVM:21:4056). Histological sections of gemmules and histological slides containing megascleres, gemmoscleres and abnormal gemmoscleres deposited in the Queen Victoria Museum \& Art Gallery: QVM:21:4057-60.

\section{Etymology}

For the type locality.

\section{Description}

Radiospongilla pedderensis forms relatively shallow encrustations, albeit often very expansive ones which, when they are mature, typically encompass the entire circumference of extended sections ( $\geq 0.8 \mathrm{~m}$ in length) of flooded tree trunks and branches. In relatively calm areas the sponge can be found growing attached to the surfaces of rocks. In addition to encrustations, $R$. pedderensis ( $\mathrm{pl} .1$ ) often produces fingerlike projections from the encrustations described previously. The surface of $R$. pedderensis is irregular and, because the ends of spicules project through the body surface, is hispid. Oscula are small, but can be seen with the naked eye. $R$. pedderensis forms an irregular network of spicules, which are held together by relatively large amounts of spongin. Living specimens of $R$. pedderensis have a compact texture and are firm when touched.

Megascleres are feebly curved to almost straight, fusiform amphioxea. The surface of a megasclere is sparsely covered with microspines that are both curved and sharp. Details of these microspines are visible only under high-power light microscopy or transmission electron microscopy (pls 2A,B).

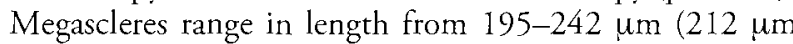
where $n=25$ ). These scleres range in width from $6.5-8.8$ $\mu \mathrm{m}(\overline{\mathrm{x}}=7.2 \mu \mathrm{m}$ where $\mathrm{n}=13)$.
Normal gemmoscleres are few in number and are polymorphic. Most commonly, the shaft of each individual microsclere of $R$. pedderensis is cylindrical and spiny. Some of these scleres are straight while others are slightly curved. The ends of gemmoscleres in $R$. pedderensis are (i) amphistrongyla, (ii) amphioxea, or (iii) one end may be blunt while the other is sharp. The gemmoscleres of $R$. pedderensis typically terminate with at least one end in the form of a coronet of very small, recurved spines. Behind the coronet, gemmoscleres usually bear a second ring of larger recurved hooks, which arise from the shaft of the sclere once it obtains full diameter (pl. 2C). Variations include lack of coronet and/or the presence of one or more straight macrospines which often give rise to an asymmetrical gemmosclere (pl. 2D). Gemmoscleres range in length from $100-136.4 \mu \mathrm{m}(\overline{\mathrm{x}}=121.2 \mu \mathrm{m}$, where $\mathrm{n}=18)$ and in width from 3.1-5.0 $\mu \mathrm{m}(\overline{\mathrm{x}}=4.4 \mu \mathrm{m}$, where $\mathrm{n}=21)$.

Abnormal gemmoscleres are straight to feebly-curved spicules. They normally possess one terminal, but not uncommonly two and rarely three widely-separated bulbous swellings (pls 2E, F). Where two or more swellings occur on a single sclere, these expansions on the spicule are cylindrical and lanceolate. Abnormal gemmoscleres are extremely plentiful in the pneumatic layer of a gemmule. These scleres range in length from 53.0-76.6 $\mu \mathrm{m}(\bar{x}=$ $68.3 \mu \mathrm{m}$ where $\mathrm{n}=12$ ) and in width from $1.4-2.2 \mu \mathrm{m}$ $(\overline{\mathrm{x}}=1.7 \mu \mathrm{m}$ where $\mathrm{n}=12)$.

Gemmules are spherical and range in diameter from 480-630 $\mu \mathrm{m}(\overline{\mathrm{x}}=528 \mu \mathrm{m}$ where $\mathrm{n}=17)$. An effective protective covering surrounds each gemmule (pl. 3A). It consists of abundant megascleres and a smaller number of gemmoscleres. Some megascleres penetrate the pneumatic

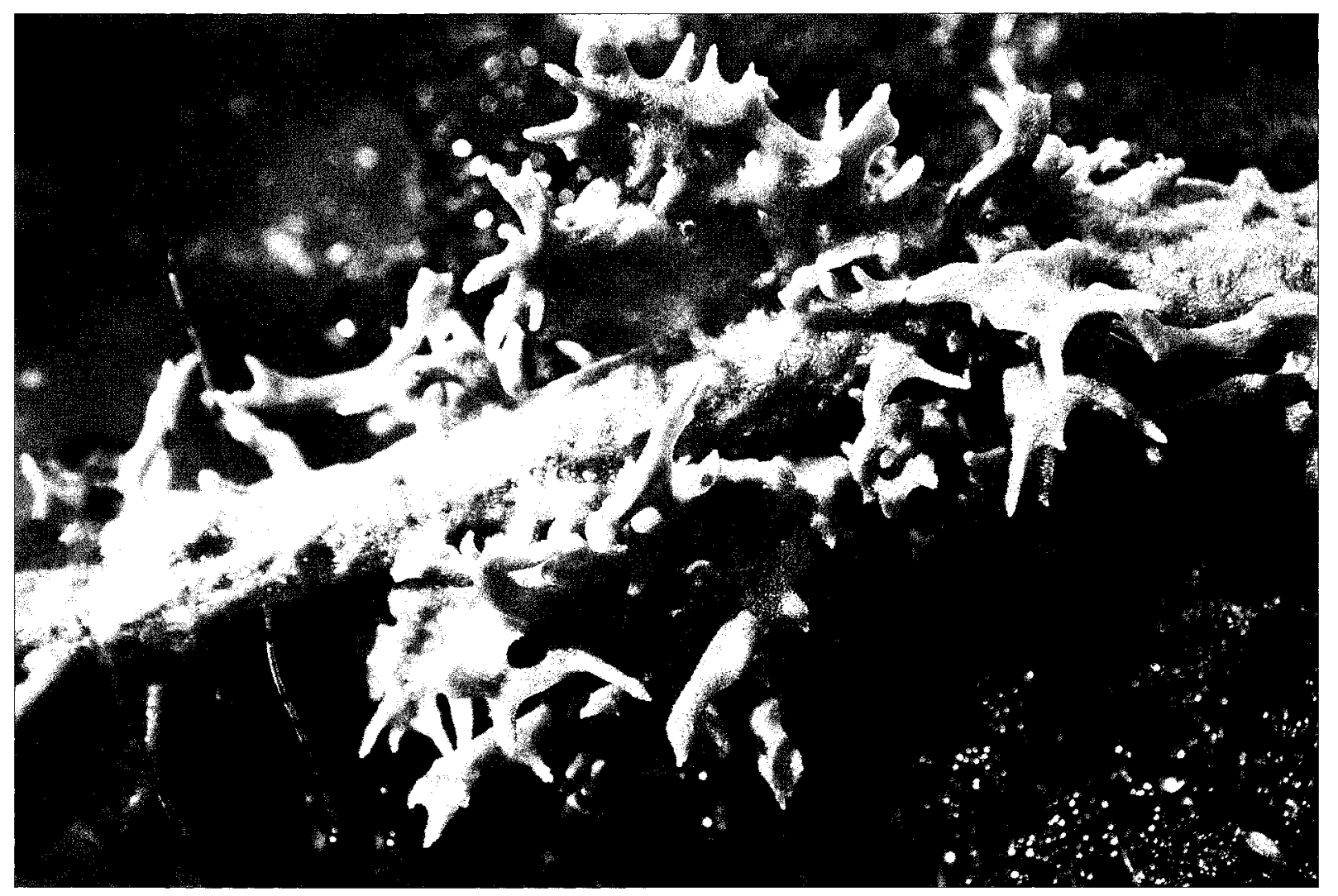

PLATE 1

A specimen of Radiospongilla pedderensis in which finger-like projections are seen to be arising from and along the base of the encrusted sponge. 

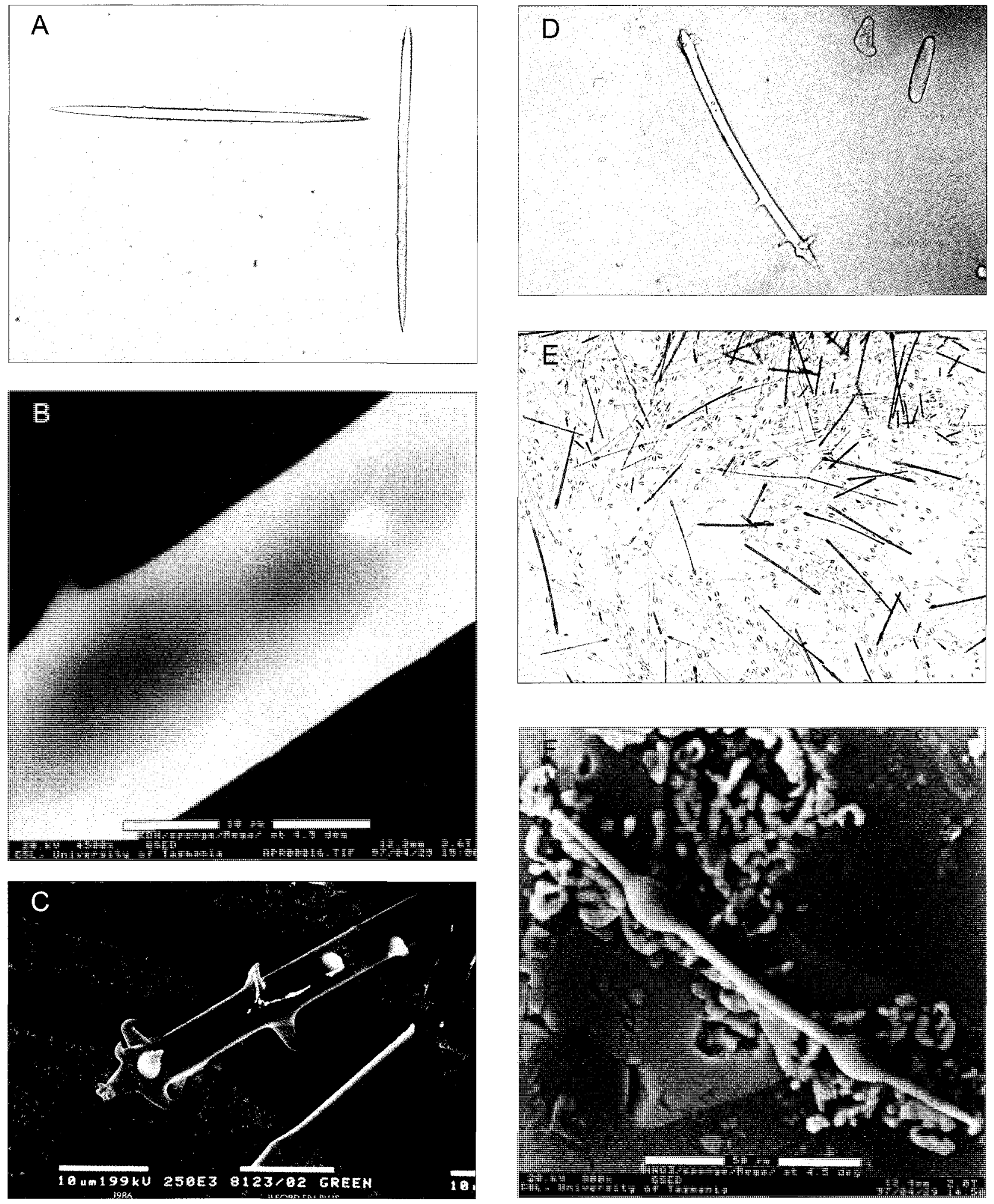

PLATE 2

(A) A megasclere from Radiospongilla pedderensis (length $226 \mu \mathrm{m}$ ) showing the general appearance of these fusiform, amphioxea scleres. Note that the surface of the megasclere is sparsely covered with microspines. (B) Transmission electron micrograph of a megasclere from R. pedderensis, showing curved microspines (single scale bar $=10 \mu \mathrm{m}$ ). (C) Transmission electron micrograph of the terminal coronet of recurved spines on a true gemmosclere from $\mathrm{R}$. pedderensis (single scale bar $=10 \mu \mathrm{m})$. (D) An abnormal gemmosclere from $\mathrm{R}$. pedderensis (length $207.9 \mu \mathrm{m}$ ) under high-power light microscopy in which straight macrospines are present. (E) Abnormal gemmoscleres from R. pedderensis under light microscopy. (These range in length from 53.0-76.6 $\mu m$ ). (F) Transmission electron micrograph of an abnormal gemmosclere from $\mathrm{R}$. pedderensis with two lanceolate swellings. (single scale bar $=50 \mu \mathrm{m}$ ). 
layer of a gemmule. The porus tube of the foramen is simple and globular in shape. The apex of the foramen protrudes above the surface of the gemmular membrane where it looks like a nipple (pl. 3B); however, this protrusion (i.e., the porus tube of the foramen) lies in a deep, conical depression. The pneumatic layer of a gemmule is filled in part with air spaces (pl. 3C).

\section{Colour}

Deep green (photic zone) to greyish-white (aphotic zone).

\section{Comparison with other species}

Since Penney \& Racek (1968) erected Radiospongilla, there have been three new species which have been ascribed to this genus in Australia and overseas, namely: Radiospongilla ornata from Argentina (Bonetto \& Ezcurro de Drago 1970; subsequently transferred to Anheteromeyenia by VolkmerRibeiro 1996), $R$. streptasteriformis from the Northern Territory, Australia (Stanisic 1979), and R. amazoniensisfrom Brazil (Volkmer-Ribeiro \& Maciel 1983)). R. pedderensis is clearly differentiated from $R$. streptasteriformis and $R$. amazoniensis. R. streptasteriformis has megascleres which are spinose, fusiform amphioxea while those of $R$ amazoniensis are stout amphistrongyla. This contrasts markedly to the megascleres in $R$. pedderensis which are more delicate, fusiform amphioxea. Most significantly the true gemmoscleres of $R$ pedderensis differ markedly from those of other local Radiospongilla spp. They are most similar to those of $R$. sceptroides but differ by the having a more incipiently spined shaft and overall greater length.

\section{DISCUSSION}

Radiospongilla pedderensis is a very common and widelydistributed spongillid in Lake Pedder in the southwest of Tasmania. The species forms moderately firm, large encrustations on flooded timber and, when specimens are protected from meaningful wave action, thinner sponges may grow on rock surfaces. Also, in calmer waters, or at greater depths, finger-like projections often grow from the surface of $R$, pedderensis.

At present the known distribution of $R$. pedderensis is within Lake Pedder, where it is widespread throughout its extensive shores to depths of at least $10 \mathrm{~m}$. The species may live at even greater depths, but sampling in those regions has yet to be undertaken. However, this species has not been observed to grow at sites where meaningful sedimentation would be deposited on their surfaces, or in sites that are exposed to heavy wave action. During calm and sunny conditions, an observer wearing polaroid sunglasses, can see very large numbers of $R$. pedderensis growing on the submerged trunks and branches of flooded trees and shrubs in the shallow regions of Starfish Inlet (GDA 94) E. 418563 and N. 5254030 .

When they live in the photic zone, specimens of $R$. pedderensis are deep green in colour. However, because the water in Lake Pedder is heavily tanninised, the depth of the photic zone is partially constrained. Specimens of $R$. pedderensis which grow beneath the photic zone are greyishwhite in appearance.

The verdant coloration of $R$. pedderensis is caused by the presence of intracellular zoochlorellae that live within the sponge cells, specifically the archaeocytes (pls 3D, E). The ellipsoidal shape of these algae, together with the presence of a cup-shaped chloroplast and a pyrenoid all suggest that they belong to the Chlorococcale group. Racek (1969) suggested that intracellular zoochlorellae were responsible for the green colour in several Australian radiospongillids; however, herein we provide the first documented evidence of such an association in a local species. Zoochlorellae have been well documented in overseas freshwater sponges (e.g., Gaino et al. 2003).

Racek (1969) also speculates that these zoochlorellae are in a symbiotic relationship with the sponge, but while this relationship has been proven experimentally in overseas freshwater sponges (Wilkinson 1980), similar studies have yet to be conducted on the local species.

At three main locations within Lake Pedder a newly described species of the sponge-fly genus Sisyra (Smithers et al. 2008) occurs. Aquatic larvae of these small lacewings (Neuroptera: Sisyridae) are found living upon $R$. pedderensis. Sponge-flies are specialised predators of freshwater sponges and they are almost invariably found only with their prey (New 2004).

When this species is collected in peak summer (i.e., January) numerous gemmules are often present. According to Penney \& Racek (1968) large numbers of gemmules are to be found in maturing sponges within Radiospongilla. When a gemmule matures in $R$. pedderensis it becomes golden-yellow in colour. In $R$ p pedderensis gemmules are to be found throughout mature sponge tissue and are relatively large when compared with those of most other Australian congeners.

Analyses of water samples from 1999 to date reveal that the temperature of Lake Pedder ranges between 5.9 and $20.5^{\circ} \mathrm{C}$. The $\mathrm{pH}$ range recorded in Lake Pedder is from 5.6 to 6.8 while conductivity, measured at $25^{\circ} \mathrm{C}$ in $\mu s$, varies between 30.4 and 46.1 over the same period. Finally, total nitrogen in Lake Pedder ranged up to a maximum of $193.94 \mu \mathrm{g} / \mathrm{l}$. Paduano \& Fell (1997) recorded water quality parameters for lakes in which another species of radiospongillid, $R$. crateriformis, grows in the state of Connecticut in the northeastern United States. Their data from those lakes reveal that $\mathrm{pH}$ varies between 6.8 and 7.1 while conductivity (again measured at $25^{\circ} \mathrm{C}$ in $\mu s$ ) ranges from 39 to 58 and total nitrogen ranged up to a maximum of $312 \mu \mathrm{g} / \mathrm{l}$. Temperature readings were not provided. Although some differences are apparent, these two radiospongillids appear to grow under very similar conditions with reference to these parameters of water quality.

\section{Expanded key to the Australian species of Radiospongilla}

1. Gemmoscleres forming a double layer, the inner radially, the outer irregularly arranged; megascleres broadly fusiform ......R. philippinensis (Annandale) Gemmoscleres forming a single layer of radial arrangement; megascleres slender fusiform ........2

2(1) Gemmular porus tube surrounded by a conical depression; immature gemmoscleres not abundant in symplasm or dermal membrane ................ Gemmular porus tube surrounded by $3-4$ mammiform aspiculous enlargements of the pneumatic coat; immature gemmoscleres usually abundant in symplasm and dermal membrane ...

R. hemephydatia (Annandale)

3(2) Megascleres armed with conspicuous spines .....4 Megascleres with microspines ..................5 

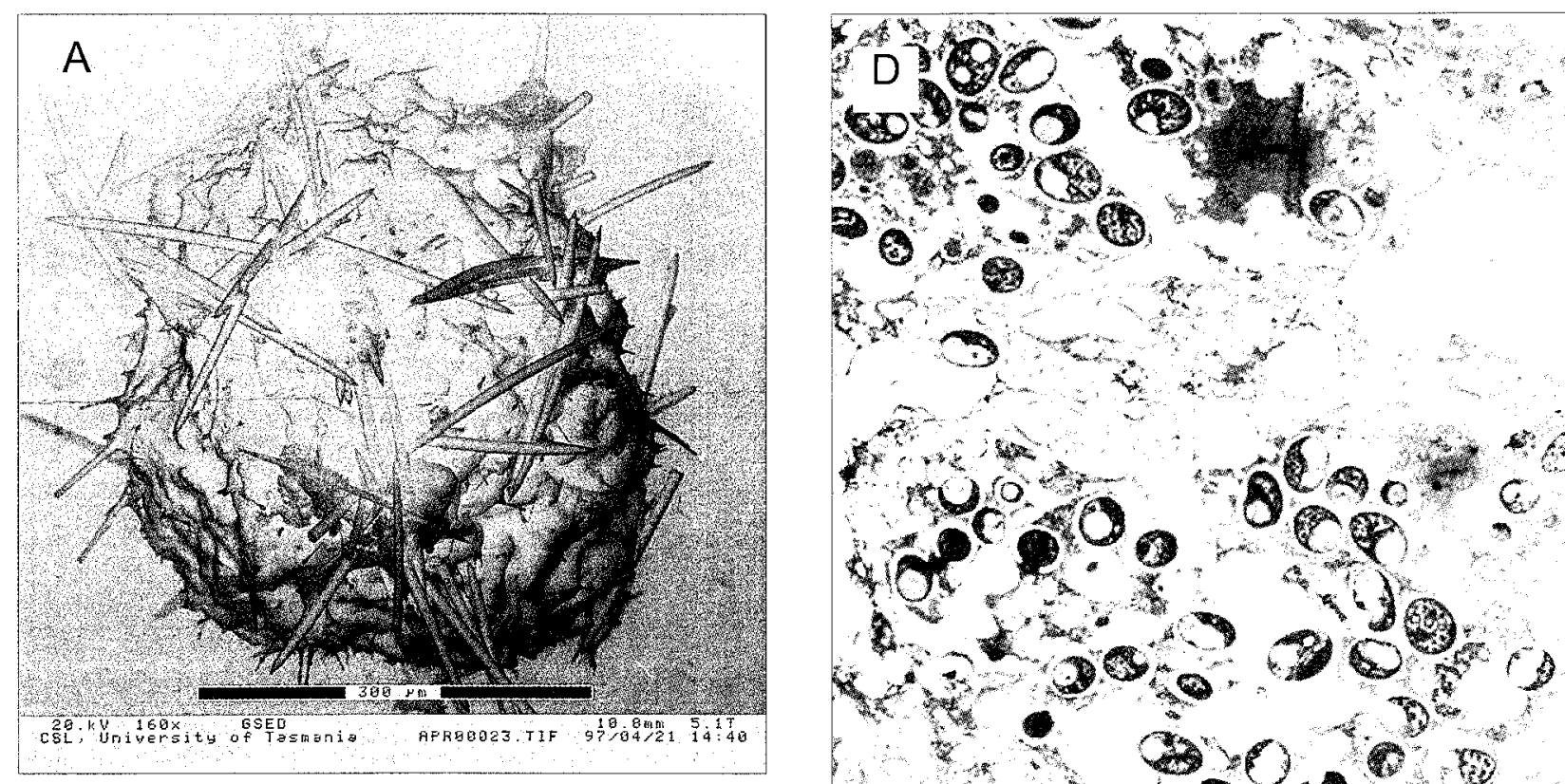

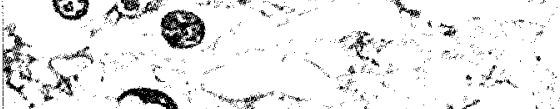

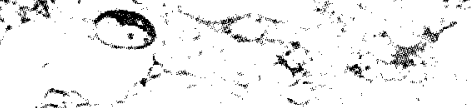

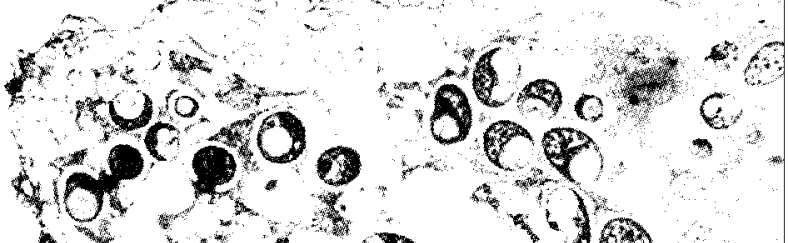

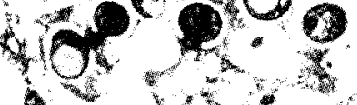

2. $30.90 \%$
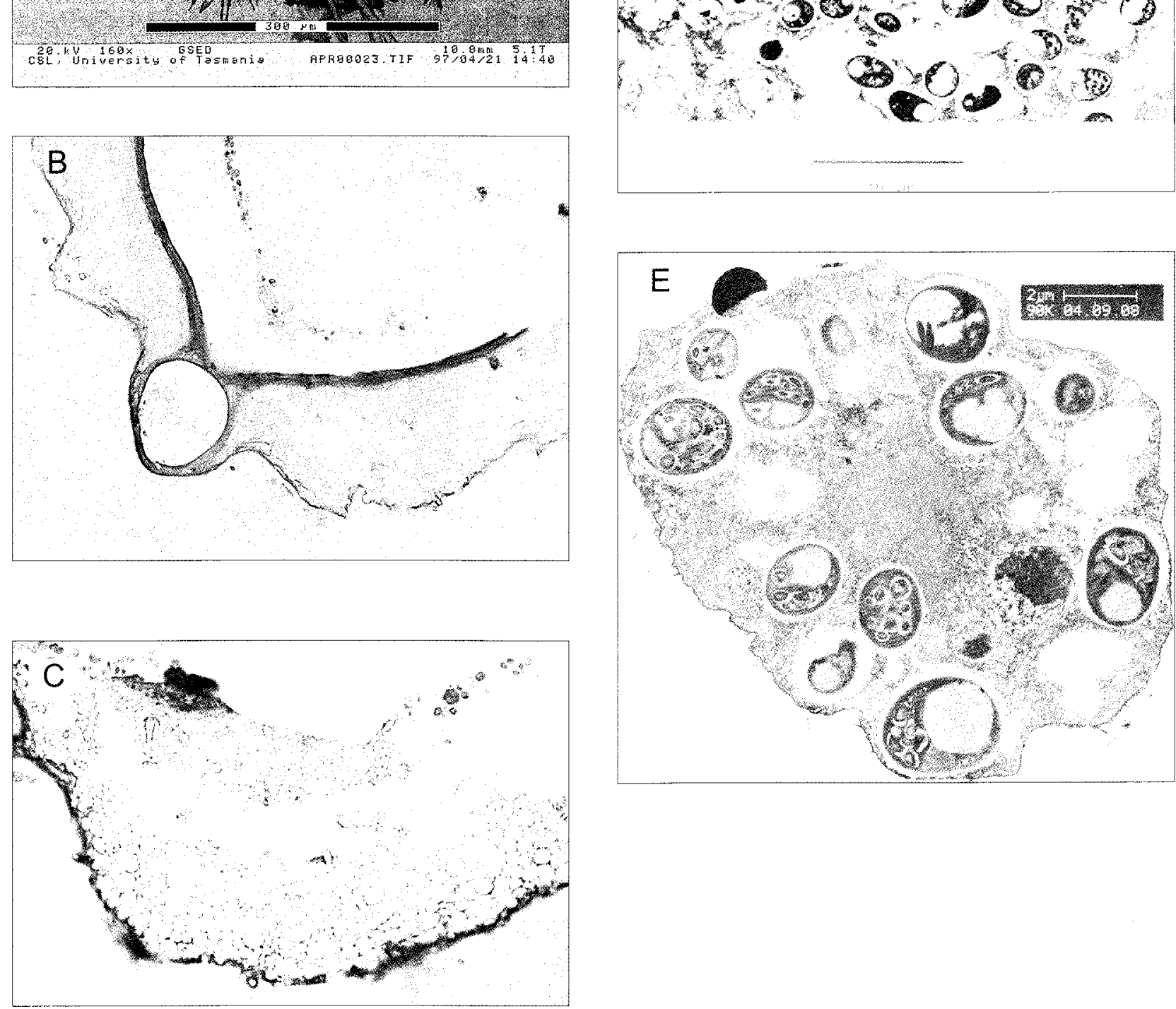

PLATE 3

(A) Transmission electron micrograph of the protective covering surrounding a gemmule from Radiospongilla pedderensis (single scale bar $=300 \mu \mathrm{m})$. (B) A transverse section of a gemmule from R. pedderensis under light microscopy depicting the single, simple, globular, gemmular porus tube (length 70um) surrounded on the external surface by a deep conical depression when viewed from above. (C) The pneumatic layer (width $55 \mu \mathrm{m}$ ) of a $\mathrm{R}$. pedderensis gemmule under light microscopy, which reveals air spaces. It is in this layer that the abnormal gemmoscleres are found. (D) Transmission electron micrograph of zoochlorellae within the general symplasm of $\mathrm{R}$. pedderensis. (Scale bar $=10 \mu \mathrm{m})($ E) Transmission electron micrograph of zoochlorellae within an individual archaeocyte of $\mathrm{R}$. pedderensis. (Scale bar $=2 \mu \mathrm{m}$ ) 
4(3) Tips of megascleres free from spines; gemmoscleres typically amphioxea ............... . synoica Racek Tips of megascleres armed with conspicuous aggregations of larger spines; gemmoscleres typically amphistrongyla ........... R. multispinifera (Gee)

5(3) Gemmules comparatively small $(310-380 \mu \mathrm{m})$ and gemmoscleres typically amphioxea R. hispidula Racek Gemmules comparatively large $(420-630 \mu \mathrm{m})$ and gemmoscleres typically amphistrongyla .........6

6(5) Gemmoscleres armed with numerous acute spines towards the extremities of the scleres R. sceptroides (Haswell)

Gemmoscleres normally amphistrongyla with few spines, sometimes with a terminal spine in continuation of the main shaft rhus giving the appearance of amphioxea.

$$
\text { R. pedderensis sp. nov. }
$$

\section{ACKNOWLEDGEMENTS}

We thank Mr David Seaton, Manager of the Launceston General Hospital's histopathology laboratory, for access to some of its facilities as well as for arranging to undertake histological sections of $R$, pedderensis gemmules for us. We also thank Dr J. Purser, Deputy Head of the School of Aquaculture at the University of Tasmania, for access to and assistance with photomicroscopy facilities and Associate Professor D. McWilliam of the School of Chemistry at the University of Tasmania for access to a chemistry laboratory which enabled us to digest $R$. pedderensis gemmules for analyses of scleres under light microscopy. Thanks also to the Central Science Laboratory of the University of Tasmania for conducting electron microscopy on (i) various types of scleres as well as (ii) gemmules from $R$. pedderensis. We greatly appreciate the work of Mrs G. Nash, electron microscopist within the Australian Antarctic Division, for the electron- micrographs that reveal the presence of zoochlorellae. With reference to field studies on Lake Pedder, we thank Messrs J. Ford and C. Livingston for (i) valuable coxswain assistance; (ii) the precise geographic location of the field sites - J.F.; and (iii) water chemistry data for Lake Pedder - C.L. The research was made possible by grants from Hydro Tasmania and the W.D. Booth Charitable Trust. Finally, support has also been forthcoming from the Queen Victoria Museum \& Art Gallery.

\section{REFERENCES}

Bonetto, A.A. \& Ezcurra de Drago, I. 1970: Esponjas de los afluentes del alto Paraná en la provincia de Misiones. Acta Zoologica Lilloana 27: 37-61.

Brown, M.J. 1999: Buttongrass moorlands. In Reid, J.B., Hill, R.S., Brown, M.J. \& Hovenden, M.J. (eds): Vegetation of Tasmania. Flora of Australia Supplementary Series 8: 286-303. ABRS, Canberra.

Flynn, T.T. 1923: On a fresh-water sponge from Tasmania. Papers and Proceedings of the Royal Society of Tasmania 1922: 58-59. [Note: The date quoted for this article has invariably been given as 1922; however, the actual publication date is 26 February 1923].

Gaino, E., Rebora, M., Corallini, C. \& Lancioni, T. 2003: The life-cycle of the sponge Ephydatia fuviatilis (L.) living on the reed Phragmites australis in an artificially regulated lake. Hydrobiologia 495:127-142.
Gooderham, J. \& Tsyrlin, E. 2002: The Waterbug Book: A Guide to the Freshwater Macroinvertebrates of Temperate Australia. CSIRO Publishing, Collingwood, Victoria: $232 \mathrm{pp}$.

Kiernan, K. 2001: The geomorphology and geoconservation significance of Lake Pedder: In Sharples, C. (ed.): Values and Restoration. Occasional Paper 27: Centre for Environmental Studies, University of Tasmania: 13-50.

Lendenfeld, R. von 1887: Die Süsswasser-Coelenteraten Australiens. Zoologische Jahrbuicher, Abteilung für Systematik, Geographie und Biologie der Thiere 2: 87-108.

New, T.R. 2004: Introduction to the Systematics and Biology of Australian Aquatic Neuroptera. Cooperative Research Centre for Freshwater Ecology: Identification \& Ecology Guide No. 49: 33 pp

Paduano, G.M. \& Fell, P.E. 1997: Spatial and temporal distribution of freshwater sponges in Connecticut lakes based upon analysis of siliceous spicules in dated sediment cores. Hydrobiologia 350: 105-121.

Pemberton, M. 2001: Soils in the Lake Pedder area. In Sharples, C. (ed.): Values and Restoration. Occasional Paper 27: Centre for Environmental Studies, University of Tasmania: 61-65.

Penney, J.T. \& Racek, A.A. 1968: Comprehensive revision of a worldwide collection of freshwater sponges (Porifera: Spongillidae). Bulletin of the United States National Museum Number 272, Smithsonian Institution Press, Washington D.C.: 184 pp.

Poirrier, M.A., Martin, P.S. \& Baerwald, R.J. 1987: Comparative morphology of microsclere structure in Spongilla alba, S. cenota and S. Lacustris (Porifera: Spongillidae). Transactions of the American Microscopical Society Inc. 106(4): 302-310.

Racek, A.A. 1969: The freshwater sponges of Australia (Porifera: Spongillidae). Australian Journal of Marine and Freshwater Research 20: 267--310.

Smithers, C.N., Forteath, G.N.R. \& Osborn, A.W. 2008: A new species of Sisyra (Insecta: Neuroptera: Sisyridae) from Lake Pedder, Tasmania. Australian Journal of Entomology 47: 77-79.

Stanisic, J. 1979: Freshwater sponges from the Northern Territory (Porifera; Spongillidae). Proceedings of the Linnaean Society of New South Wales 103(2): 123-130.

Volkmer-Ribeiro, C. 1996: Acanthodiscus new genus and Anheteromeyenia redefined (Porifera, Spongillidae). Iheringia, Série Zoologia, Porto Alegre 81: 31-43.

Volkmer-Ribeiro, C. \& Maciel, S.B. 1983: New freshwater sponges from Amazonian waters. Amazoniana Kiel 8(2): 255-264.

Weltner, W. 1895: Spongillidenstudien III. Katalog und Verbreitung der bekannten Süsswasserschwämme. Archiv für Naturgeschichte 61(1): 114-144.

Weltner, W. 1900: Süsswasser-Schwämme In Semon R. (ed.): Zoologische Forschungsreisen in Australien und dem Malayischen Archipel. Denksshriften der medicinischnaturwissenschaftlicher Gesellschaft zu Jena 8(5): 519523.

Weltner, W. 1910: Spongillidae. In Michaelsen, W. \& Hartmeyer, R. (eds): Die Fauna Sïdwest-Australiens: 3(5): 137-144 G. Fischer, Jena.

Wilkinson, C.R. 1980: Nutrient translocation from green algal symbionts to the freshwater sponge Ephydatia fuviatilis. Hydrobiologia 75: 241-250.

Williams, W.D. 1980: Australian Freshwater Life: The Invertebrates of Australian Inland Waters. Macmillan, South Melbourne, Victoria: $321 \mathrm{pp}$.

(accepted 7 October 2008) 